Annals of Warsaw University of Life Sciences - SGGW

Horticulture and Landscape Architecture No 39, 2018: 55-69

(Ann. Warsaw Univ. of Life Sci. - SGGW, Horticult. Landsc. Architect. 39, 2018)

DOI 10.22630/AHLA.2018.39.6

\title{
The role of the countryside in strengthening the green infrastructure system WrOF based on the example of Chrzanów village
}

\section{JOWITA PYSZCZEK}

Faculty of Environmental Engineering and Geodesy, Wrocław University of Environmental and Life Sciences

\begin{abstract}
The role of the countryside in strengthening the green infrastructure system WrOF based on the example of Chrzanów village. The landscape is dynamic, and it undergoes constant changes which are clearly visible in places of intensive human activity. In the existing natural system, there are the phenomena of landscape fragmentation, including the disappearance of high greenery, river basin regulations, and the transformation of agricultural land into development sites. This problem can be noticed in places of urban sprawl and also the expansive settlement of rural areas located in their close proximity. The areas around cities play what is for them an important protective role. However, the border between a city and the countryside is a place of increased urbanisation and a disappearance of high greenery or open spaces. Such activities weaken the city's green infrastructure system, which leads to a decreasing of its protective function, threatens biodiversity and disturbs the spatial landscape arrangement. For the Wrocław Functional Area (WrOF), in 2014 a project for a green infrastructure system was prepared, the implementation of which is designed to prevent these negative phenomena. The chance to strengthen the system is to use the potential that the green area has in the villages located in this area. This paper aims to present the possibilities of the Chrzanów village landscape, which can strengthen the green infrastructure system WrOF. It will be presented based on the example of Chrzanów village using the Sector Analysis of the Landscape Interior.
\end{abstract}

Key words: green infrastructure, Wrocław Functional Area WrOF, village, Chrzanów, Sector Analysis of the Landscape Interior

\section{INTRODUCTION}

\section{General outline of the topic and its problematic aspects}

Together with population growth the negative consequences connected with growing development are visible. In cities and their close surroundings, green areas are disappearing as a result of development for residential, service and industrial functions. The problem of the excessive urbanisation of rural areas is a phenomenon common not only in Poland. The threat to nature is not only from the development of built-up areas, but also its fragmentation, which leads to a decrease of its value and the possibilities of covering it with various forms of protection. Green complexes are subject to fragmentation, both as a result of growing development and incorrectly designed transport networks. The development of road infrastructure to a large extent takes place on urban and agricultural land and in forested areas (Angelstam et al. 2017a). In order to prevent this negative phenomenon, it is recommended thoughtfully to use space by encouraging the use of public transport and promoting a sustainable transport system (Dworni- 
czak 2013). It is important to create connections between the city's green infrastructure elements and its surroundings - both open spaces and rural areas that create valuable zones around cities. For the correct functioning of rural areas, it is important to care for the elements which make up the natural environment, which were an integral part of the rural landscape in the past. Greenery in built-up areas blurs the impression that buildings are separated elements from the environment (Serafin 1958). Spatial planning allows for the harmonious management of existing resources by creating multifunctional areas in terms of their use by man and by nature. This also concerns the GI, understood as the "strategic planning of a high quality network of natural and semi-natural areas of environmental features designed and managed so as to provide a wide range of ecosystem services and protection of biodiversity both in rural and urban areas. In particular, the GI (...) aims to increase nature's ability to provide numerous valuable good and ecosystem services, such as: clean air or water" (European Commission 2013). Investment in the green infrastructure and its development is one of the crucial elements of the EU policy in the scope of biological diversity and nature preservation (European Environmental Agency 2011). What's more, green infrastructure is a combination of the natural resources (existing greenery forms) with coordinated functions, which have an effect on each other constantly.

The European Landscape Convention, signed in Florence on 20 October 2000, ratified by Poland on 27 September 2004, and in operation since 1 January 2005, stresses that the landscape is "a key element of individual and social well-being and that its protection, management and planning carries entailed rights and responsibilities for everyone". Landscape is a space perceived by people as "containing natural elements and products of civilisation, whose character is the result of the action and interaction of natural and/or human factors" (European Landscape Convention 2000). In the non-urbanized area, we distinguish between several types of landscape, depending on the proportion of agricultural management and forest management. Natural components of the agricultural landscape are agricultural lands, permanent grassland, gardens, orchards, water reservoirs, non-forest woodlands and parks, reserves and natural monuments (Tłoczek 1966). Components connected with the presence of the high greenery are the most valuable with regard to its possibilities to strengthen the GI, the value of which, and its practical and aesthetic benefits, increase with age (Zaraś-Januszkiewicz et al. 2008). Forested areas, used in a communicated public space, decrease and regulate road traffic speed and also create a friendlier environment for pedestrians (Burden 2006, Jaszczak et al. 2012). Deciduous trees also play an important role in preserving biodiversity, among others as a source of food for large herbivores (Angelstam et al. 2017b), or serving as shelter for small vertebrates, birds, and insects (Zaraś-Januszkiewicz et al. 2009).

In designing a new space and transforming an existing one, it is important to take into consideration the human factor. The residents of areas located in/at the GI system can draw from it benefits that are both material and psychological 
(Shackleton et al. 2016, Derkzen et al. 2017). For the correct functioning of the environment, where humans are present, it is crucial to care for the existing forms of greenery, regardless of their scale, strengthening the existing ones by forming new connections or by conferring on them a particular landscape value and, by extension, legal protection and, with time, even creating greenery systems from scratch. The Chrzanów village case study aims to determine whether the village and its surroundings, located at the edge of the designed green infrastructure system of the Wrocław Functional Area, have the potential to strengthen this system and, by extension, answer the question whether to include it in the planned structure.

\section{MATERIAL AND METHODS}

\section{The green infrastructure of WrOF against the background of other countries' solutions}

GI systems adopt various forms depending on the existing types of development: high greenery, medium and small, surface waters (rivers, watercourses, reservoirs, lakes, and the like), and location of protected areas. Ontario's "green belt" in Canada contains valuable natural elements - water systems, native species of fauna and flora and natural heritage in the form of forests, marsh lands, rivers, and lakes (Carter-Whitney 2010). The green ring around London (England) comprises 1.2 million acres of greenery surrounding the metropolis, protecting rural areas against uncontrollable development and construction pressure and, by extension - the loss of the rural character of an English village (Amati et al. 2006). Another form is a green structure of 160,000 hectares called the green heart of Holland. It is located between the biggest cities: Amsterdam, Utrecht, Rotterdam, and Den Haag. The three leading landscapes there are: peatlands, river landscapes and desiccated lakes, which are a peculiar showcase of Holland. Another example is a finger-shaped greenery arrangement in Copenhagen (Denmark), the "Copenhagen Finger Plan". This ensures comfortable access to the closest green areas (among others, thanks to adequate public transport links) and enables control of the expanding building development, and protection of open rural areas (Carter-Whitney 2010).

\section{General description of the WrOF}

Wrocław is the fourth biggest city in Poland in terms of population (GUS 2015), located in the south-west part of the country, and is the capital of the Lower Silesia region. A comprehensive approach to shaping the green infrastructure, both in the area of the city and in areas connected to Wrocław, will limit the negative impact of the city.

The Functional Area is an "area of a particular phenomenon in the scope of land management consisting of functionally connected grounds characterised by common conditions and forecasted uniform development goals" (Act of 27 March 2003 on land planning and management). The Wrocław Functional Area presents a knot zone, which comprises the central city of Wrocław and its direct surroundings which are functionally connected with it (Studium Spójności Funkcjonalnej we Wrocławskim Obszarze Funkcjonalnym, n.d.). It comprises 3 urban municipalities, 10 urban-rural communes, and 16 rural communes. 
In 2014 the Territorial Development Institute commissioned a project for the optimal arrangement of green infrastructure in WrOF (Niedźwiecka-Filipiak et al. 2015). This is a ring and edge-shaped model, through the centre of which runs the river Odra - a particularly important watercourse - whilst maintaining the river's morphological consistency (KPZK 2030 2011). The WrOF GI system consists of three green rings, marked in the study as R1, R2, and R3, of ecological, climatic and landscape functions, and wedges combining them, based on the Odra's tributaries (Fig. 1). Moreover, the GI system is also directed towards people, serving them as recreational and leisure areas. The R1 ring is located around Wrocław and is a filter between the city and its buildings and rural areas combined with recreational areas. The $\mathrm{R} 2$ is a ring of dominating function as a wildlife corridor and one-day trip areas for residents of Wrocław and surrounding areas. The R3 ring has a tourist-recreational function, for trips of several days. At the

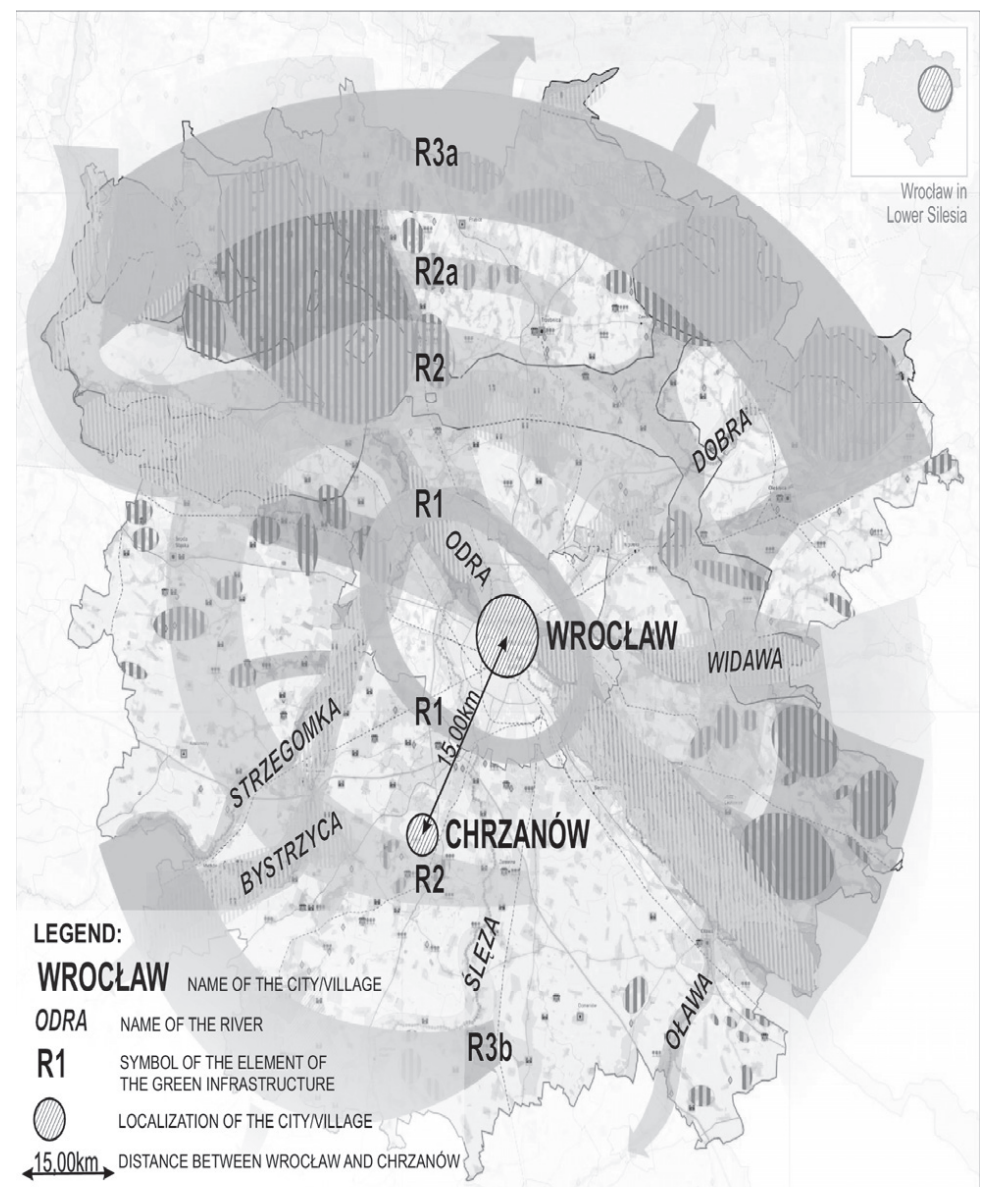

FIGURE 1. Chrzanów location in the model of ideological GI system WrOF (prepared by J. Pyszczek based on Niedźwiecka-Filipiak et al. 2015) 
same time, it is also a crucial element of the GI system because it creates a connection of supra-local ecological hubs Barycz Valley in the north and Sudeckie Przedgórze in the south (Niedźwiecka-Filipiak et al. 2015).

\section{Countryside versus green infrastructure system - case study Chrzanów}

When thinking about strengthening the green infrastructure by the countryside, it is important to notice the potential in villages located inside and on the border of the GI system as constituent elements. Chrzanów is a part of the Kobierzyce commune and Wrocław poviat (Fig. 1). It was chosen for analysis due to the active residents of the village (according to the Central Statistical Office in 2011 there were 169 of them $^{1}$ ) who participate in the Village Revitalisation Programme and who have the same idea of the village's future development, based on the production and promotion of horseradish - hence the slogan for the themed village "Chrzanów - the Village of Spicy Taste [from translator: the first part of the name Chrzanów (chrzan) means horseradish] (Golis 2015). This is in accordance with the function that the $\mathrm{R} 2$ ring is to have in the designed GI system, thus including the village would be beneficial. In turn, the current way of managing the village may have a negative or positive impact on the existing green systems in the village's surroundings, its existing con-

\footnotetext{
${ }^{1}$ Local Data Bank webpage https://bdl.stat.gov. pl/BDL/start; Jednostka terytorialna: Chrzanów; Kategoria: Narodowe Spisy Powszechne; Grupa: NSP 2011 - Ludność; Podgrupa: Ludność w miejscowościach statystycznych (Wymiary: Płeć), ogółem [last update:18.12.2014].
}

nections, or create connections between existing structures complementing them with simultaneous strengthening. Due to this fact, several analyses were carried out to show the possibilities of incorporating the village into the designed GI WrOF system. The analyses were carried out in two parts: the first part, the general analysis, includes the village surroundings in its administrative boundary; the second concerns a detailed analysis of the village, inside it, and along the main road. The analysis associated with the built-up area, due to the functional division, is related to public greenery, that is, greenery accompanying communication, and houses, located on the sport and sacral areas and the like (Tłoczek 1966). This article presents the research carried out on the basis of cataloguing green forms present in Chrzanów village area and also on the scale of a street, where private green areas play an important role (front garden), and greenery located in public places (fairways, lanes). In order to strengthen the third dimension analyses, a Sector Analysis of the Landscape Interior (SALI) was performed.

\section{RESULTS AND DISCUSSION}

\section{Greenery around Chrzanów village}

The south border of Chrzanów village area is located on the border of the R2 ring in the GI WrOF system (Fig. 2). The ring consists of many natural elements in the Chrzanów surrounding, like Bystrzyca Valley National Park to the southwest (which is also a part of the R2 and a wedge, connecting R1 around Wrocław with R2), also many forests, forested areas, mid-field trees, and streams to the 


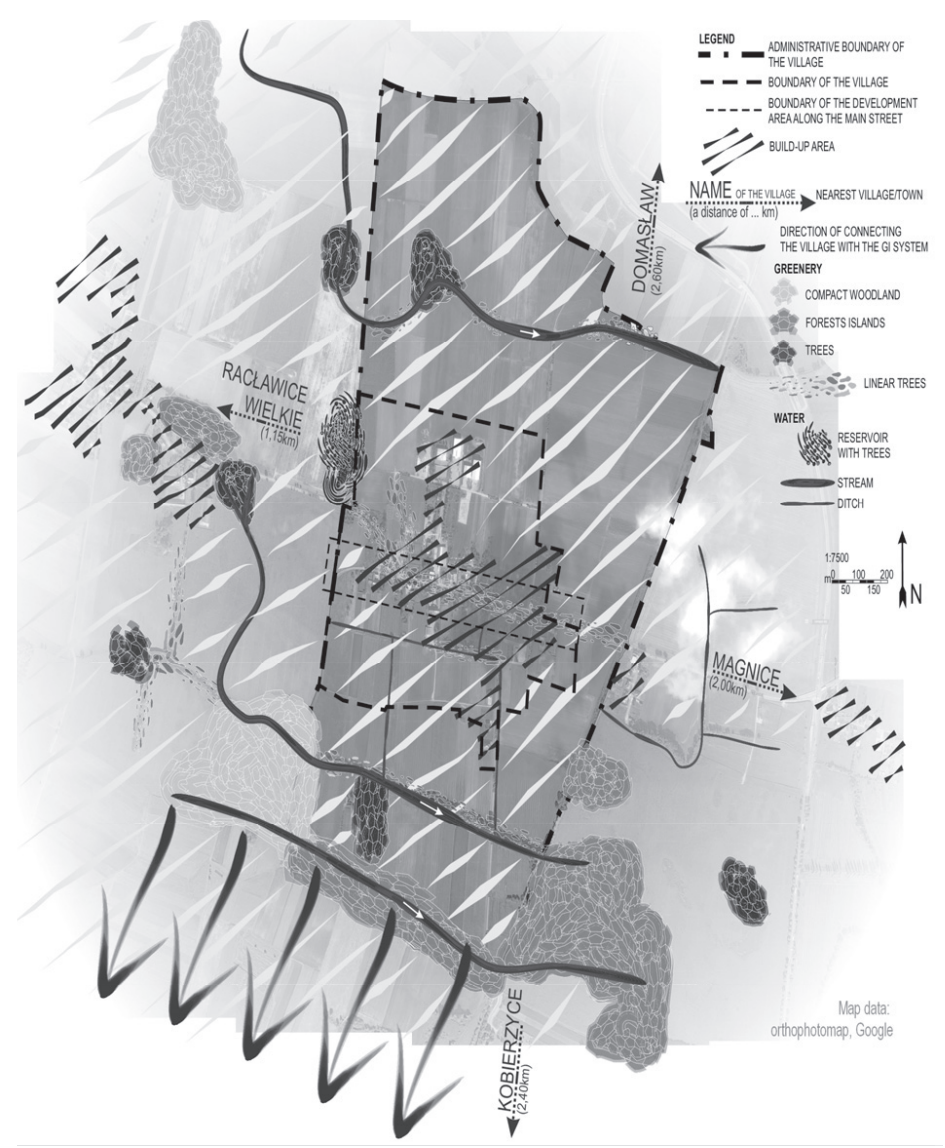

FIGURE 2. Chrzanów connections with greenery structure outside the built-up area in the scale of the village area (prepared J. Pyszczek)

south. In this direction, it is necessary to look for the village's connection with the system; however, its parallel arrangement, and parallel watercourses catchment against the ring, do not favour it. Around the village, there are numerous forested areas, and forest groups close to the buildings of Racławice Wielkie, and in the form of a larger forest complex in the south part of Chrzanów area, at the exit for Kobierzyce. The village area and its closest surroundings are also characterised by closed forests - which in the north-west form part of the area border. In order to connect the village with the system, particular attention needs to be paid to the forms of high greenery, located in the south of the village, watercourses with forest concentrations and trees in line, and the fact that around the built-up areas, in whole throughout the village, there are cultivated fields. 


\section{Greenery inside the village}

Depending on the ownership rights, in the villages there are areas of widely available greenery used by each resident, and areas of private greenery located on the properties of individual residents. Public green areas in villages mainly comprise: village parks, squares, greenery accompanying communication (e.g. alleys, lanes), greenery accompanying watercourses and reservoirs in the village, green areas accompanying various public facilities (e.g. churches, schools, community centres), sport and leisure areas (e.g. sports playgrounds). Management of private areas in a village also has a great influence on shaping the greenery, including front gardens that shape the interior of streets and gardens, areas directly connecting buildings with village surroundings.

In the past, traditional front gardens in the Lower Silesia region were vegetable gardens with herbs, blossoming perennials and, whenever possible (depending on the size), with bushes and fruit trees. Currently, the composition and selection decide on the type of front garden, which option is a subjective decision of the property owner. This may result in a front garden traditional for Lower Silesian villages or a modern garden - with visible tendencies referring to city projects focussing on ease of maintenance (small conifers in the form of a lane, formed evergreen plants, a lawn, and very few or a complete lack of perennials), or mixed. Dzięciołowska and Latkowska (2009) notice in their research in the area of Podlasie that an increasing number of modern gardens result in the degradation of the village cultural landscape, and that the front gardens no longer play an ap- plicative function (usually there are single fruit plants). The situation is similar when it comes to Lower Silesian village gardens. In relation to the "modernisation" of front gardens and gardens in general, which is connected with a lack of high and deciduous greenery, more valuable in strengthening village green infrastructure are areas with high greenery, in the form of individual trees, alleys, and lanes that are located on public land.

The Chrzanów village analysis concerns the interior of the village that constitutes the roadway along the main Lipowa Street. It consists of the main street, a pavement on the right side of the street, greenery along pedestrian lanes (a pavement and a path on the north side), common areas - bus stops, recreational areas with street furniture - and front gardens, private areas which directly shape the interior. The high greenery is closely integrated with the area under analysis, both in the public and private spheres (Fig. 3). In the road lane there is the oldest line planting in the village in the form of a line of Lindens (14 units). In the western part of the village, there are also 2 younger poplar lines. The highest saturation with high deciduous greenery can be observed in the central part of the village, where the highest density of traditional front gardens is also located.

For the analysis of the front gardens, 3 types of management were adopted: traditional (flower-vegetable with herbs, sometimes bushes, fruit trees), modern (a lawn with conifers, geometrically formed plants) and mixed (species both traditional for a village and ones relating to city models). In Chrzanów village, for 62 building plots there are 13 traditional 

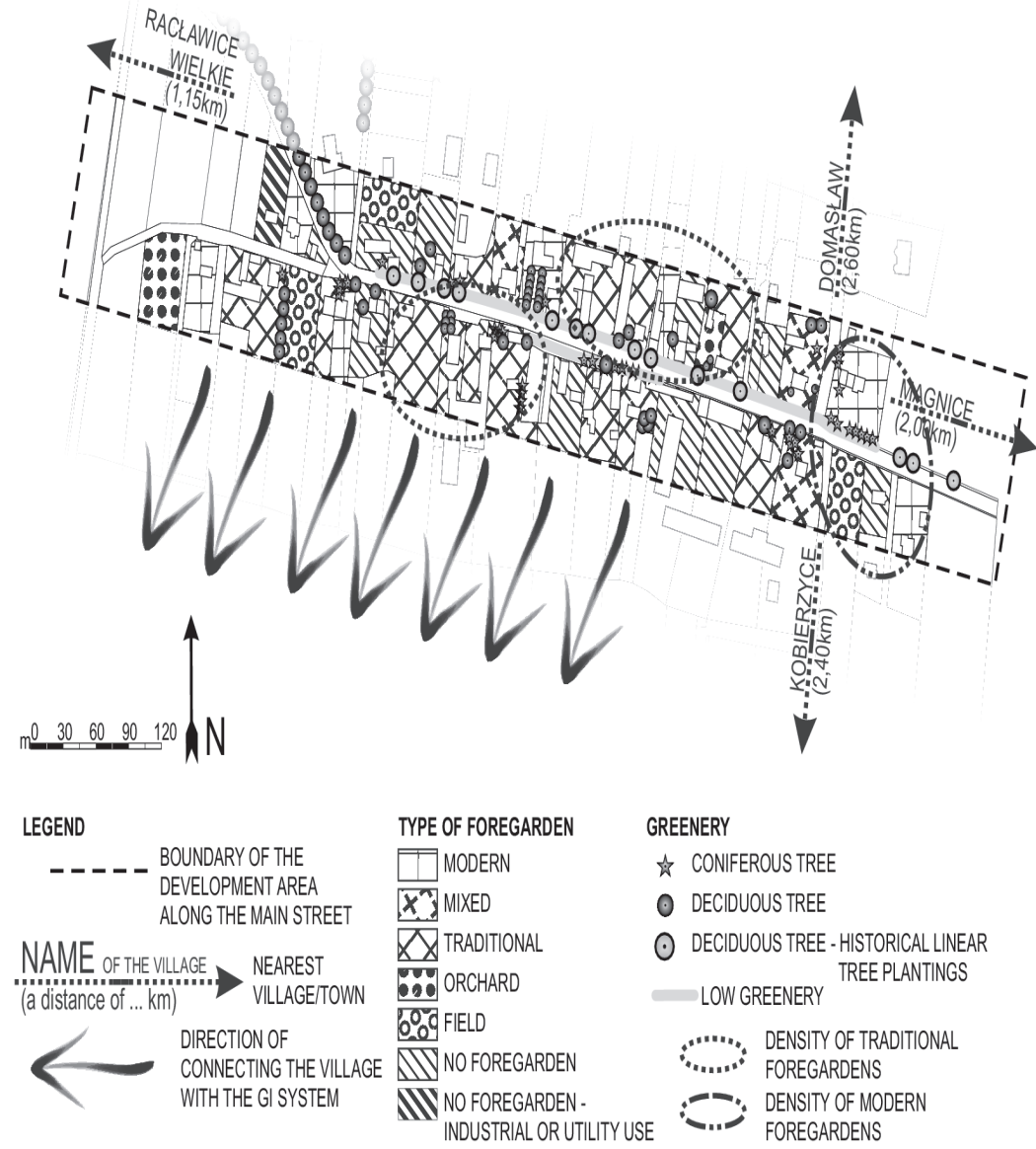

FIGURE 3. Greenery analysis along the main street - high greenery and front gardens (prepared by J. Pyszczek)

front gardens (one connected with an orchard - apple trees), 8 modern ones and 3 mixed. Modern management appears mainly on newly built properties (depending on the construction stage, many plots haven't yet been developed with greenery). The analysis also takes into account plots that are not built-up, but which are located directly in the street belt. Their development is connected with agricultural functions - a cultivated field and an orchard. In the front gar- dens that constitute private residencies, 84 trees (48 are deciduous and 36 are conifers, whereas in 3 cases they form a tall hedge) were identified. Deciduous trees also appear in a large number in public areas along the roadway in the form of line planting. Along the main Lipowa Street, there is a lane of linden trees, the oldest in the village and then changing into a line of aspens towards Racławice Wielkie. 


\section{The third dimension (interiors)}

The next step involved research in the third dimension by means of a Sector Analysis of the Landscape Interior (SALI). It aimed at determining what percentage share the greenery has, especially whether a high one, in the interior as a street. In the research, the scope of the analysis in relation to SALI Niedźwiecka-Filipiak (2009), was increased in order to cover the whole interior, that is a $360^{\circ}$ panorama. The research covered mainly the village through road, Lipowa Street. This is complemented by the third dimension of the front gardens and street greenery analysis, shown on the village plan. The interior for analysis was marked approx. every $100 \mathrm{~m}$ (the distance was slightly amended due to the location of communication hubs). As a result, five panoramic photos were taken of the $360^{\circ}$. This aimed at evaluating the biggest scope of data that could be read from such a photograph (Fig. 4). The second step of the analysis involved the subjective evaluation of each element of which the interior consists, by assigning it a positive, negative, or neutral category. The last stage of SALI is the scoring (very good -3 points, good -2 points, satisfactory -1 point, unsatisfactory -0 points) of each sector (according to the categories "greenery, form, historic value, species composition"). After summing up the points, sectors are shown where, depending on the number of points, they are classified as exemplary, neutral or those that need strengthening on the basis of the negative elements highlighted in the SALI analysis. In this research, the most important element chosen for analysis and evaluation is the category connected with the greenery, hence the method was modified to take this into account. Such an evaluation allows for the verification of the condition of the greenery located in the interior, whether due to age issues this evaluation is valuable, refers to the history of the place, and also whether the species applied in the private and public areas are harmonious with the rules for maintaining the rural landscape.

In strengthening the GI WrOF, high greenery is of great importance. Its (trees) percentage share in each interior shows that there is the least of it in the interior 2 (4.5\% regarding the whole interior on the analysed panoramic photograph of $\left.360^{\circ}\right)$; in turn, the highest share was recorded in interior $3(35.8 \%)$. In the remaining three interiors, it came in between $7.8-10.0 \%$ (Fig. 5).

The high greenery in Chrzanów village mainly comprises deciduous trees - located both on private property and on public land in the form of Linden alley, Poplar alley and small woodland groups and individual trees. Evaluation of elements concerning, among others, low, medium and high greenery was verified on the basis of 80 sectors (each 5 interiors in the scope of the $360^{\circ}$ divided into 16 sectors).

Interior 3 received the highest score (75/96 points - the sum of all the maximum points from 16 sectors) - Figure 6 . Here is the greatest number of high greenery elements, both deciduous and conifers in good technical condition, as well as trees that form the remains of historic Linden alley. What is more, the species composition of the middle greenery (deciduous bushes) is pertinent to the village's character, occurring not only in private front gardens but also in street frontages, along the pavement. The inte- 


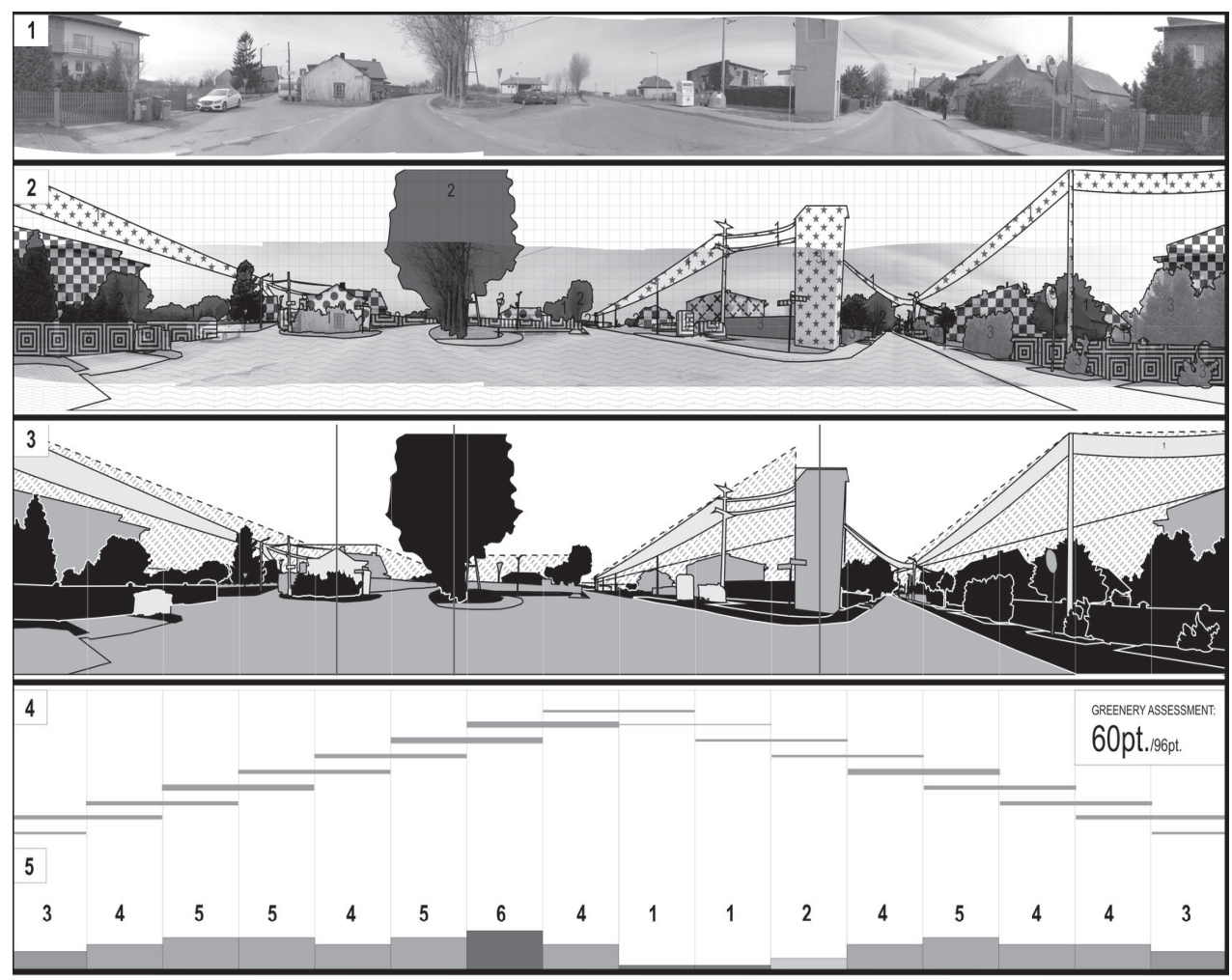

\begin{tabular}{|c|c|c|c|c|c|c|c|c|c|}
\hline \multirow[t]{2}{*}{1} & $\begin{array}{l}\text { INTERIOR no. } 1 \text {, } \\
\text { PANORAMA } \\
\text { RANGE } 360^{\circ}\end{array}$ & 2 & $\begin{array}{l}\text { SECTOR ANALYSIS OF } \\
\text { INVENTORY } \\
\square \text { LOW GREENERY } \\
\text { MEDUMM GREEEERY } \\
\text { HIIGH GREENERY }\end{array}$ & \multicolumn{2}{|c|}{ 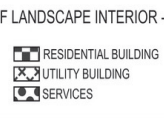 } & \multicolumn{2}{|c|}{ 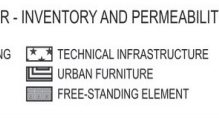 } & $\begin{array}{l}\text { TY [\%] OF COMPO } \\
\qquad \begin{array}{l}\text { STREET } \\
\text { PAVEMENT/ } \\
\text { ROADSIDE }\end{array}\end{array}$ & $\begin{array}{l}\text { NENTS } \\
\begin{array}{l}\text { PERMEABILITY } \\
\begin{array}{|l|l}125 \% \\
2 & 50 \% \\
375 \%\end{array} \\
3\end{array}\end{array}$ \\
\hline & 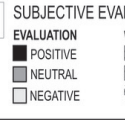 & 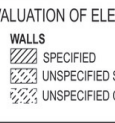 & $\begin{array}{l}\text { EMENTS, WALLS IN THE } \\
\text { SUBJECTVE } \\
\text { OOBJECTVE }\end{array}$ & & $4 \mathrm{CV}_{\mathrm{CR}}^{\mathrm{E}}$ & $\begin{array}{l}\text { VALUATIOI } \\
\text { RIERRAA }\end{array}$ & $\begin{array}{l}\text { N OF THE INTERIORAC } \\
=\text { GREENERY }\end{array}$ & $\begin{array}{l}\text { CCORDING TO CRI } \\
\begin{array}{l}\text { EVALUATION } \\
\end{array}\end{array}$ & 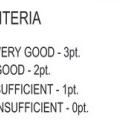 \\
\hline 5 & $\begin{array}{l}\text { DIAGRAM - SUM C } \\
\text { AND IT } \\
\text { EVALUATION } \\
\text { EXEMPLARY } \\
\text { SUFFCIENT }\end{array}$ & $\begin{array}{l}\text { I OF ALL POINTS F } \\
\text { ITS EVALUATION } \\
\square \text { VERY GOOD } \\
\text { INSUFFIIIENT }\end{array}$ & $\begin{array}{l}\text { FOR EACH SECTOR } \\
\text { GOOD } \\
\text { UNACCEPAABLE }\end{array}$ & & $\begin{array}{l}\text { GREENERY ASS } \\
\text {..pt./96pt. }\end{array}$ & SESSMENT: & $\begin{array}{l}\text { EVALAATION OF THE GREE } \\
\text { MAXXIMUN NUMER OF }\end{array}$ & $\begin{array}{l}\text { ENERY IN THE ITERIOF } \\
\text { NTSS.96 pt. }\end{array}$ & SUM OF 16 SECTORS) \\
\hline
\end{tabular}

FIGURE 4. SALI for interior 1, explaining the scope (prepared by J. Pyszczek)

rior which shows the least potential for strengthening WrOF according to SALI was marked as 4 . The "greenery" category received one of the lowest scores - 31-96 points - this is the result of a slim percentage of low, medium and high greenery occurrence in the central point of the interior, its bad technical condition (badly cut fruit trees), the dominance of conifers over deciduous trees, and a gap in the historic Linden alley at the point of taking the panoramic picture. Remaining interiors have an average approximate scoring, i.e.: interior $1-60$ points, interior $2-64$ points and interior 5 54 points. 


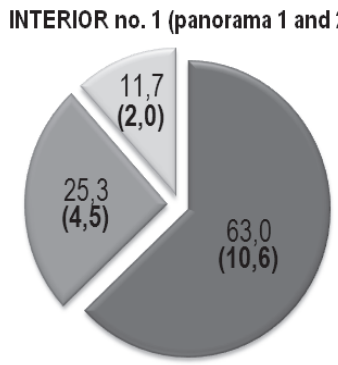

INTERIOR no. 4 (panorama 7 and 8)

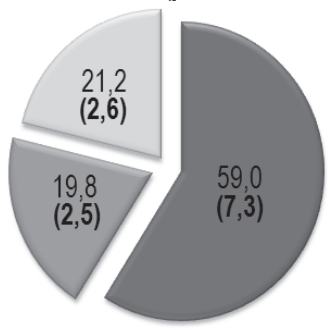

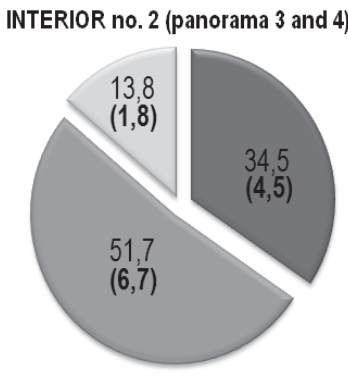

INTERIOR no. 5 (panorama 9 and 10)

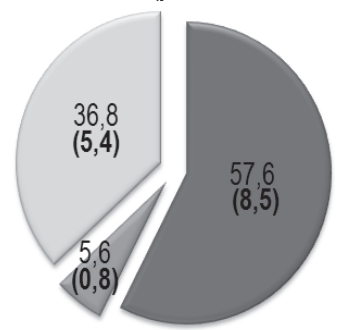

INTERIOR no. 3 (panorama 5 and 6 )

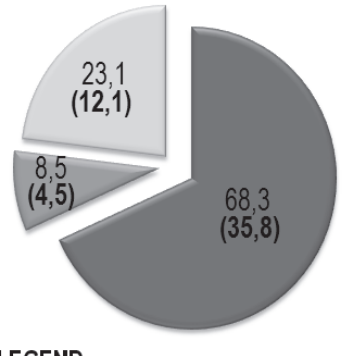

LEGEND

The percentage of:

10,0 - the type of greenery in the overall greenery of the interior

$(10,0)$ - the type of greenery in the interor

a high greenery

medium greenery

$\square$ low greenery

FIGURE 5. Percentage share of greenery in interiors 1, 2, 3, 4 and 5 (prepared by J. Pyszczek)

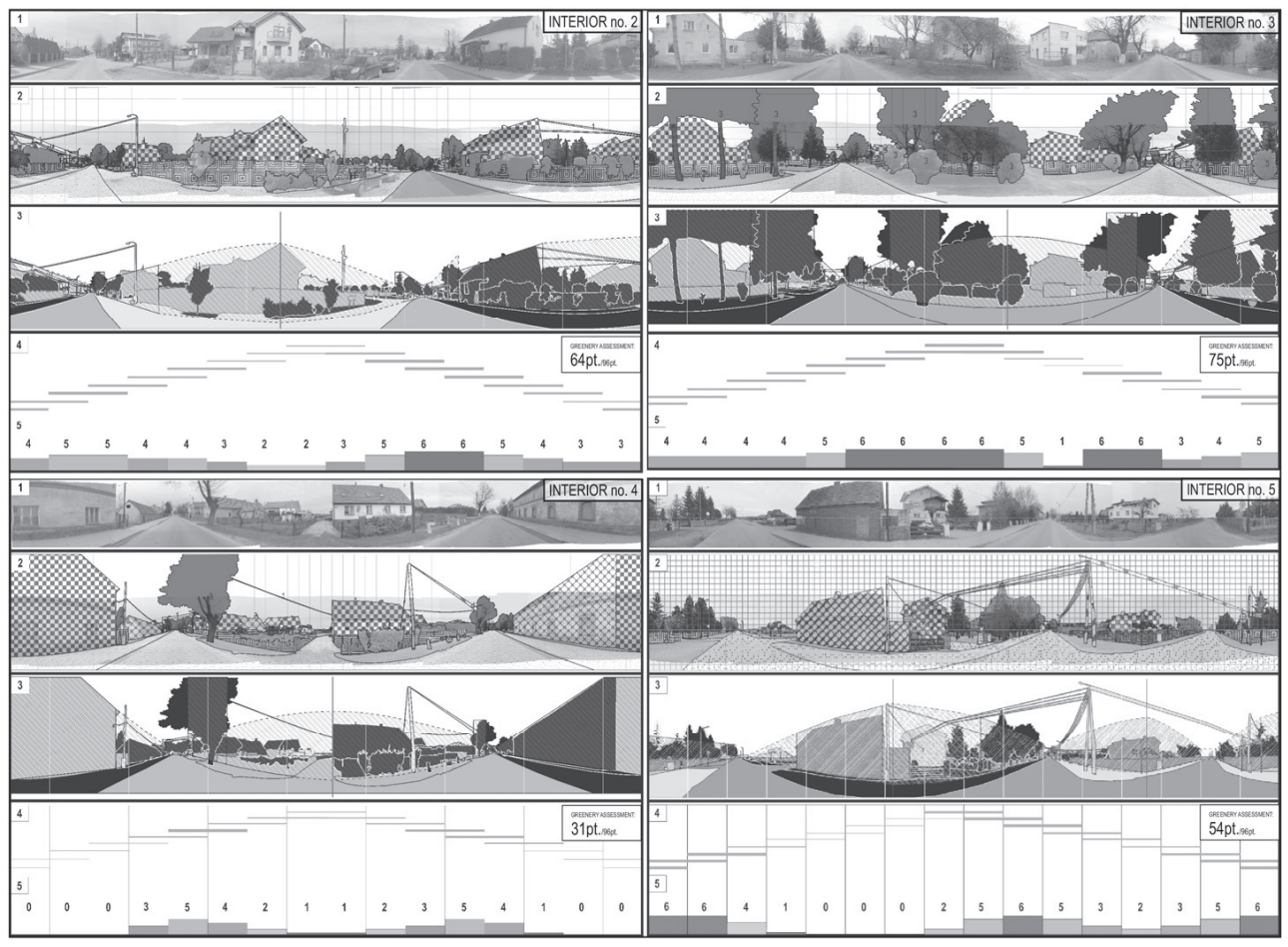

FIGURE 6. SALI for interior 2, 3, 4 and 5 (prepared by J. Pyszczek) 
An additional threat for the village is new development which is being built in the areas of previous agricultural functioning, resulting from the chaotic settlement of an exogenous population in terms of space and in the choice of new planting, not connected with traditional species (Fig. 7). Thereby, the open area of protection that functions for the village, separating Chrzanów village from the dual carriageway, gets shorter.

Imposition of the two analyses - concerning front gardens and high greenery on the plan and SALI in the third dimension - shows the most bio-diversely valuable places by the main road in the village, and also those that require intervention in order to enrich it in this respect.

\section{CONCLUSIONS}

Chrzanów village, located on the north border of the R2 WrOF green ring, requires protection against threats, such as excessive, uncontrolled building development in its southern and eastern parts.

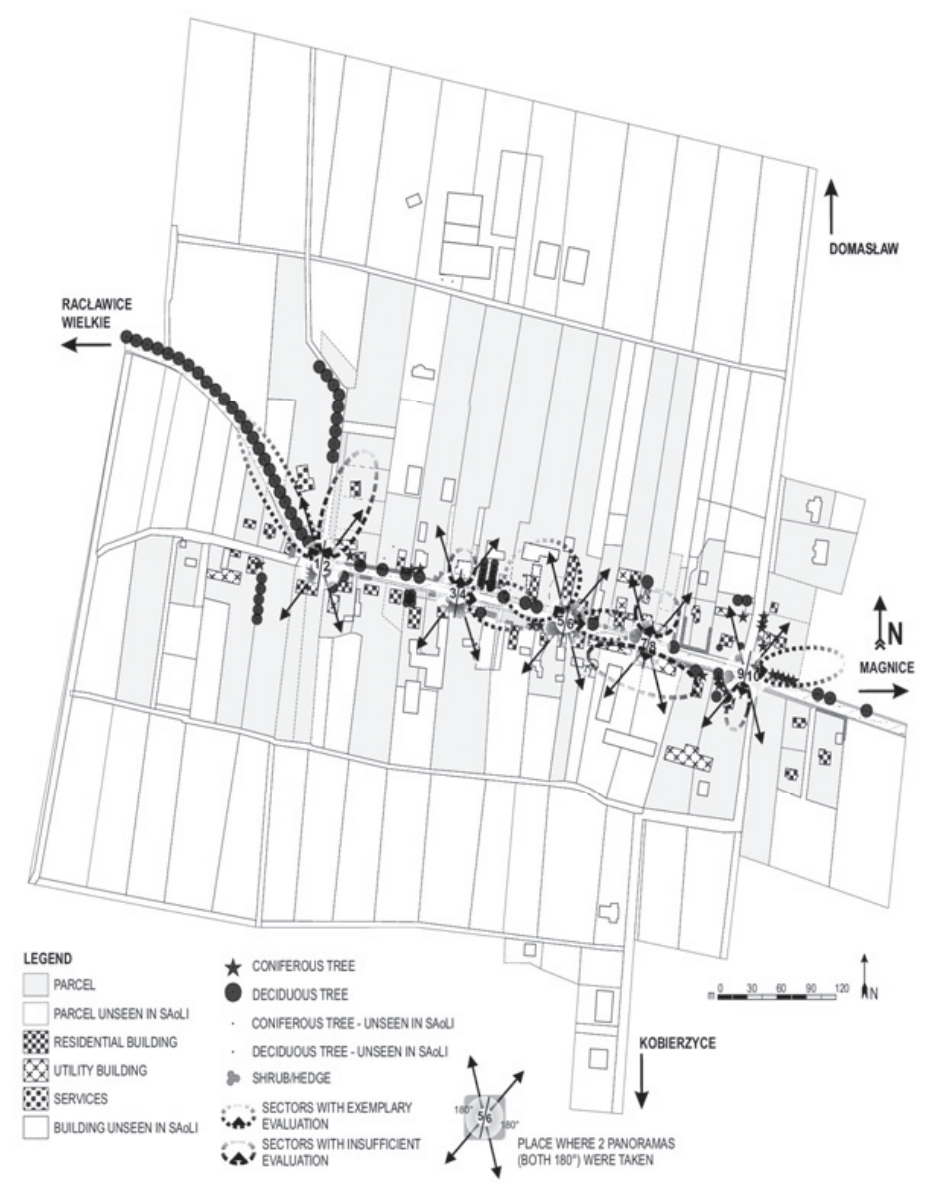

FIGURE 7. SALI in the second dimension on the plan of Chrzanów village (prepared by J. Pyszczek) 
Apart from changing the purpose of the agricultural land into built-up areas, new developments stand out due to having a species composition not harmonious with the rural character. In this article, Chrzanów village was subject to methods such as a Sector Analysis of the Interior Landscape and greenery evaluation within the village aiming at verifying whether this village can strengthen the GI WrOF. From the research, it transpires that connecting the village with the $\mathrm{R} 2$ ring is possible on the village's southern part, where there are located forested areas, groups of trees, linear plantings of trees and two small streams (flowing parallel to the ring) and two ditches, connected with the stream, orientated perpendicularly to the $\mathrm{R} 2$. This connection is possible by complementary planting with high greenery in the area of forest islands, maintaining the agricultural function of the agricultural fields (not using them for development, but leaving them as open space), and preserving the watercourses and their natural character. The village itself is showing potential in strengthening the system due to the occurrence of high greenery on public and private property, a rich choice of bush species and perennials. In Chrzanów there are new initiatives - line planting along streets, a square devoted to pollinators and flower boxes annually planted with perennials. The village's potential for strengthening the GI WrOF system results not only from the existing greenery arrangements, but also from the activities of its residents who identify with the place and desire the village to be a human friendly aesthetic environment, at the same time rich in greenery and in harmony with the rural landscape.

\section{Acknowledgements}

I would like to thank Irena Niedźwiecka-Filipiak, Head of the Institute of Landscape Architecture at Wrocław University of Environmental and Life Sciences, for her insightful comments and immense knowledge that she shared with me.

\section{REFERENCES}

AMATI M., YOKOHARI M. 2006: Temporal Changes and Local Variations in the Functions of London's Green Belt. Landsc. Urban Plan. 75 (1-2): 125-142.

ANGELSTAM P., KHAULYAK O., YAMELYNETS T., MOZGERIS G., NAUMOV V., CHMIELEWSKI T. J., ELBAKIDZE M., MANTON M., PROTS B., SVIATASLAU VALASIUK S. 2017a: Green infrastructure development at European Union's eastern border: Effects of road infrastructure and forest habitat loss. J. Environ. Manag. 193: 300-311.

ANGELSTAM P., PEDERSEN S., MANTON M., GARRIDO P., NAUMOV V., ELBAKIDZE M. 2017b: Green infrastructure maintenance is more than land cover: Large herbivores limit recruitment of key- stone tree species in Sweden. Landsc. Urban Plan. 167: 368-377.

BURDEN D. 2006: 22 Benefits of Urban Street Trees. Retrieved from: http://www. walkable.org/download/22_benefits.pdf

CARTER-WHITNEY M. 2010: Ontario's Greenbelt in an International Context. Canada.

DERKZEN M.L., TEEFFELEN A.J.A., VERBURG P.H. 2017: Green infrastructure for urban climate adaptation: How do residents' views on climate impacts and green infrastructure shape adaptation preferences? Landsc. Urban Plan. 157: 106-130.

DWORNICZAK Ł. 2013: Ochrona i gospodarowanie krajobrazem Wrocławskiego Obszaru Funkcjonalnego w świetle Eu- 
ropejskiej Konwencji Krajobrazowej. Politechnika Wrocławska, Wrocław. Retrieved from: http://www.dbc.wroc. pl/Content/24303/dworniczak_ochrona_PhD.pdf

DZIĘCIOLOWSKA M., LATKOWSKA M.J. 2009: Rural front gardens in Podlasie (Hajnówka county). Ann. Warsaw Univ. of Life Sci. - SGGW, Horticult. Landsc. Architect. 30: 79-87.

European Commission 2013: Building a Green Infrastructure for Europe. Retrieved from: http://ec.europa.eu/environment/nature/ecosystems/docs/green infrastructure broc.pdf.

European Environmental Agency 2011: Green infrastructure and territorial cohesion. The concept of green infrastructure and its integration into policies using monitoring system. Technical report. Copenhagen.

European Landscape Convention. Florence, 20.10.2000. Council of Europe. European Treaty Series 176.

GUS 2015: Miasta największe pod względem liczby ludności - stan na dzień 31.12.2015. Retrieved from: http://stat. gov.pl/statystyka-regionalna/rankingistatystyczne/miasta-najwieksze-pod-wzgledem-liczby-ludnosci/.

GOLIS A. 2015: Sołectwo Chrzanów. Retrieved from: http://www.chrzanow.kobierzyce.pl/o-nas/solectwo-chrzanow.

JASZCZAK A.A., ŻUKOWSKA J., DREKSLER B. 2012: The role of greenery and traffic calming measures in road infrastructure planning, Ann. Warsaw Univ. Life Sci. - SGGW, Horticult. Landsc. Architect. 33: 141-151.

Koncepcja Przestrzennego Zagospodarowania Kraju 2030 (KPZK 2030), przyjęta przez rząd w grudniu 2011 r. [Concept of the national land development 2030 (KPZK 2030), adopted by the government in December 2011].

NIEDŹWIECKA-FILIPIAK I. 2006: Proponowana metoda sektorowej analizy wnętrz krajobrazowych jako integralna część opracowań dla programu Odnowa
Wsi. Uniwersytet Przyrodniczy we Wrocławiu, Wrocław.

NIEDŹWIECKA-FILIPIAK I. 2009: Wyróżniki krajobrazu i architektury wsi Polski południowo-zachodniej. Wydawnictwo Uniwersytetu Przyrodniczego we Wrocławiu, Wrocław.

NIEDŹWIECKA-FILIPIAK I., POTYRAŁA J., FILIPIAK P. 2015: Contemporary management of green infrastructure within the borders of Wrocław Functional Area (WrOF). Architektura Krajobrazu 2 (47): 4-27.

POTYRAŁA J., NIEDŹWIECKA-FILIPIAK I., ZIEMIAŃSKA M., FILIPIAK P. 2012: Waloryzacja widoków jako element studium krajobrazowego na przykładzie gminy Paczków, Paczków.

SERAFIN S. 1958: Architektura i krajobraz wsi. Katedra Architektury i Planowania Wsi Politechniki Warszawskiej, Warszawa.

SHACKLETON C.M. et al. 2016: How important is green infrastructure in small and medium-sized towns? Lessons from South Africa. Landscape Urban Plan. http://dx.doi.org/10.1016/j.landurbplan.2 016.12 .007

Studium Spójności Funkcjonalnej we Wrocławskim Obszarze Funkcjonalnym [Study of Functional Cohesion in the Wrocław Functional Area] n.d. Starostwo Powiatowe we Wrocławiu, Instytut Rozwoju Terytorialnego, Powiatowy Zakład Katastralny we Wrocławiu, Biuro Rozwoju Wrocławia, Gmina Kąty Wrocławskie, Gmina Siechnice, Gmina Wołów, Wołów.

TŁOCZEK I. 1966: Kształtowanie zieleni w krajobrazie wiejskim. PWN, Warszawa.

WISZEWSKI P., ŻERELIK R. 2015: Wielkie zmiany wiejskiego świata. Monografia historyczna gminy Kobierzyce, Wrocław.

Ustawa z dnia 27 marca 2003 r. o planowaniu i zagospodarowaniu przestrzennym [Act of 27 March 2003 on land planning and management]. Journal of Laws 2003 No 80 , item 717 . 
ZARAŚ-JANUSZKIEWICZ E.M., GRĄZIEWICZ A. 2008: Greenery forming of the Boyen Fortress. Ann. Warsaw Univ. of Life Sci. - SGGW, Horticult. Landsc. Architect. 29: 225-236.

ZARAŚ-JANUSZKIEWICZE., WAŚNIEWSKA M. 2009: Native greenery participation in chosen court parks of North Mazowsze dendroflora formation. Ann. Warsaw Univ. of Life Sci. - SGGW, Horticult. Landsc. Architect. 30: 189-199.

Streszczenie: Rola wsi we wzmacnianiu systemu zielonej infrastruktury WrOF na przyktadzie wsi Chrzanów. Krajobraz jest dynamiczny, ulega ciągłym przemianom, które są szczególnie widoczne w miejscach o intensywnej działalności człowieka. W istniejących systemach przyrodniczych występują zjawiska fragmentacji krajobrazu, w tym zanikania zieleni wysokiej, regulacji koryt rzecznych oraz przemian gruntów rolnych na tereny budowlane. Można ten problem zauważyć w miejscach rozprzestrzeniania się miast, a także ekspansywnego zasiedlania terenów wiejskich położonych w ich bliskim sąsiedztwie. Tereny wokół miast pełnią istotną dla nich funkcję ochronną. Granica między miastem i obszarem wiejskim to strefa zwiększonej urbanizacji i zanikania zieleni wysokiej czy przestrzeni otwartych, a te działania negatywnie wpływają na system zielonej infrastruktury miasta, prowadząc do osłabienia jej funkcji ochronnej, zagrażająć bioróżnorodności oraz zaburzając układ przestrzenny krajobrazu. Dla Wrocławskiego Obszaru Funkcjonalnego (WrOF) opracowano w 2014 r. projekt systemu zielonej infrastruktury, którego wdrożenie ma zapobiegać tym negatywnym zjawiskom. Szansą na jego wzmocnienie jest wykorzystanie potencjału, który ma zieleń we wsiach położonych na tym obszarze. Celem referatu jest ukazanie możliwości krajobrazu wsi Chrzanów, który może wzmocnić system zielonej infrastruktury WrOF. Zostanie to przedstawione na przykładzie wsi Chrzanów z wykorzystaniem metody sektorowej analizie wnętrz krajobrazowych (SAWK).

Stowa kluczowe: zielona infrastruktura, Wrocławski Obszar Funkcjonalny WrOF, wieś, Chrzanów, sektorowa analiza wnętrz krajobrazowych

MS received: 13.02 .2018

MS accepted: 09.07.2018

\section{Author's address:}

Jowita Pyszczek

Instytut Architektury Krajobrazu

Wydział Inżynierii Kształtowania Środowiska

i Geodezji

Uniwersytet Przyrodniczy we Wrocławiu

ul. Grunwaldzka 55, 50-357 Wrocław

Poland

e-mail: jowita.pyszczek@upwr.edu.pl j.k.pyszczek@gmail.com 